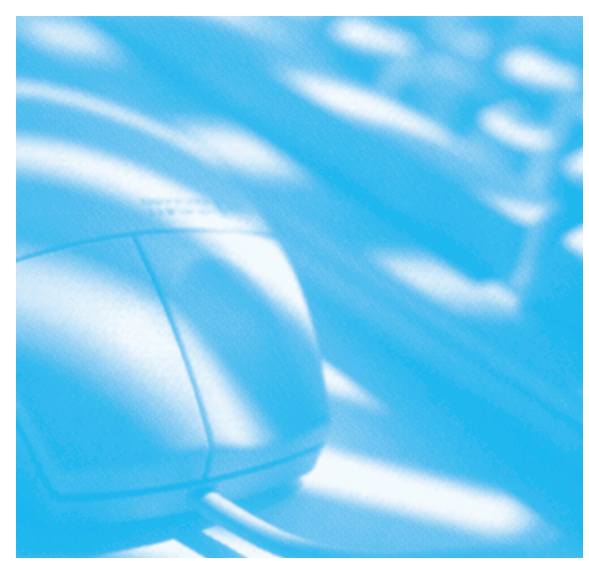

\section{Inequality and political power}

To the editor,

There is a well-documented relationship between social inequities and health, and this has led to a search for ways to improve health through addressing these inequities. Is this something that is amenable to scientific study?

In most societies, elimination of injustice has been a recurrent but an unsolved issue. The lack of a scientific perspective has hindered the process. Rawls considers that for justice to exist there must be some kind of re-distribution of resources. ${ }^{1}$ A proper allocation of capital, he says, allows valuable investment for the benefit of the most disadvantaged people. Rawlsian proposals, leaving aside the difficulties of their implementation, generate other unsolved utilitarian questions, like the search for the greatest welfare for the greatest number of people. But persistent utopian or rhetorical proposals won't address the problem that the rich are getting richer and the poor are getting poorer.

In her July 2000 Op-Ed, Starfield reminds us that poverty-related health consequences cannot be wholly explained by material deprivation, since they are not alleviated substantially by providing alms to lighten the burden of the poor. ${ }^{2}$ We must therefore elucidate the underlying mechanisms linking poverty to illness and find interventions to reduce the effects of inequity on health.

Health and illness have social and political roots, besides the biologic ones. Political power generates an uneven distribution of income because the people in power may act with the assumption that everyone should be dedicated to competition and struggle. Economic power can be the base for further enlargement of personal political power.

I have argued that a better quality of political power may reduce the social vectors that tend to impoverish mankind. ${ }^{3}$ A standardized educational program about the appropriate use of political power may lead to refined leadership practice, possibly leading to greater societal equality. It might also be possible - with systematic vigilance and the use of new medical diagnostic tools ${ }^{4}$ — to prevent people with psychopathic personalities from occupying leadership positions. ${ }^{4}$

Salvador Vale

Psychiatrist

Antiguo Hospital Concepcion Beistegui

Regina 7

Mexico D.F.

svale@df1.telmex.net.mx

Competing interests: None declared

West J Med 2000;173:376

References

1 Rawls J. A Theory of Justice. Cambridge: Harvard University Press, 1971.

2 Starfield B. Is equity a scientific issue? West J Med 2000;173:7.

3 Vale S. Poverty: 5000 years of utopian proposals have failed to solve it. Available at: http://www.bmj.com/cgi/ eletters/319/7204/203. Accessed August 3, 2000.

4 Intrator J, Hare R, Stritzke P, et al. A brain imaging (single photon emission computerised tomography) study of semantic and affective processing in psychopaths. Biol Psychiatry 1997;42:96-103. 